\title{
MENINGKATKAN HASIL BELAJAR SISWA \\ PADA MATA PELAJARAN FIQH MELALUI PENERAPAN STRATEGI BINGO
}

\author{
Zaenudin \\ APII (Asosiasi Pendidik Islam Indonesia), \\ Jawa Tengah, Indonesia. \\ zaenudinudin623@yahoo.com
}

\begin{abstract}
Abstrak
Penulisan artikel ini dilatarbelakangi oleh adanya kecenderungan para guru mata pelajaran fiqh yang menggunakan metode ceramah dalam proses pembelajaran. Dengan kata lain, tidak ada variasi metode yang digunakan dalam mengajar. Hal ini berdampak pada rendahnya prestasi belajar siswa. Berdasarkan situasi yang ada, dibutuhkan kemajuan dalam proses belajar mengajar Fiqih. Oleh karena itu, penelitian ini dilakukan bertujuan untuk meningkatkan prestasi belajar siswa dalam subjek melalui penerapan strategi bingo. Berdasarkan indikator keberhasilan tindakan yang ditentukan melalui 3 siklus penelitian, yaitu: hasil belajar siswa mencapai batas klasik keberhasilan $(\geq 85 \%)$ semua siswa yang telah mencapai keberhasilan individu (Skor $\geq 60$ ) dan sebagian besar siswa (75\%) secara aktif terlibat dalam pembelajaran atau telah dikuranginya dominasi guru pada proses pembelajaran. Ini menunjukkan bahwa belajar prestasi siswa Fiqih melalui menerapkan strategi bingo semakin meningkat. Oleh karena itu, strategi bingo dapat menjadi solusi untuk meningkatkan prestasi belajar siswa pada mata pelajaran Fiqih.
\end{abstract}

Kata kunci: pencapaian hasil belajar, fiqh, strategi bingo 


\begin{abstract}
IMPROVING STUDENTS' LEARNING OUTCOMES ON THE SUBJECTS OF FIQH THROUGH THE IMPLEMENTATION OF BINGO STRATEGY. The writing of this article was effected by the tendency of teachers of figh subjects in using the method of lectures in the learning process. In other words, there was no variation in the methods used in teaching. It is affected to the low achievement of students in learning. Based on the existing situation, it needs progress in the process of teaching and learning fiqh. Therefore, this research was conducted to improve learning achievements of students in the subject through the implementation of the strategy of bingo. Based on indicators of the success of the action that is specified by the 3 cycles of research, they are: learning results students achieve success of classical limit $(\geq 85 \%)$ all of students who have achieved individual success (Score $\geq 60)$ and most of the students (75\%) are actively engaged in learning or the dominance of the teacher has been reduced in the learning process. This shows that learning achievement of students through applying the strategy of bingo. Therefore, the strategy of bingo can be a solution to improve the learning achievements of students in the subjects of fiqh.
\end{abstract}

Keywords: learning achievement, fiqh, bingo strategy

\title{
A. Pendahuluan
}

Mata Pelajaran Fiqih adalah salah satu mata pelajaran Pendidikan Agama Islam yang diarahkan untuk menyiapkan peserta didik untuk mengenal, memahami, menghayati terutama dalam ibadah sehari-hari, yang kemudian menjadi dasar pedoman hidup (way of life) melalui kegiatan bimbingan, pengajaran, latihan, penggunaan pengalaman dan pembiasaan (Badan Standar Nasional Pendidikan, 2007: 328). Dengan demikian pembelajaran Fiqih tidak hanya dengan mendengarkan apa yang diuraikan oleh guru mata pelajaran Fiqih tetapi siswa melalui kegiatan bimbingan, latihan serta pembiasaan dalam kegiatan pembelajaran.

Hal ini sesuai dengan standar isi Madrasah Tsanawiyah yang dikeluarkan oleh Departemen Agama Republik Indonesia (2006: 37), bahwa materi yang diajarkan pada tingkat Madrasah Tsanawiyah untuk mata pelajaran Fiqih meliputi: Thaharah, Wudhu, Salat, Zakat, Puasa, Haji serta kegiatan muamalah, dengan 
menitik beratkan pada kemampuan menggali nilai, makna apa yang terkandung dalam dalil dan teori dari fakta yang ada. Jadi Fiqih tidak saja merupakan transfer of knowledge, tetapi juga merupakan pendidikan nilai (value education). Dalam pembelajaran Fiqih ditemukan beberapa kelemahan antara lain: waktu yang terbatas tetapi materi pembelajaran begitu padat, dan lemahnya sumber daya guru dalam pengembangan pendekatan dan metode yang lebih variatif, serta kurangnya sarana pelatihan dan pengembangan (Badan Standar Nasional Pendidikan, 2007: 328).

Untuk mencapai apa yang diharapkan dalam Badan Standar Nasional Pendidikan dan Standar Isi tersebut masih banyak permasalahan yang dihadapi baik oleh guru dan siswa. Diantaranya adalah minimnya kemampuan guru dalam mengembangkan suasana pembelajaran yang mendukung bagi siswa untuk belajar dan pengembangan pendekatan dan metode pembelajaran yang belum bervariasi, misalnya dengan suatu permainan da-lam kegiatan belajar mengajar. Kondisi ini berakibat pada hasil belajar siswa masih ren-dah, hal ini dibuktikan dari hasil Ulangan Tengah Semester yang berjumlah 38 siswa, sebanyak 30 atau sekitar $79 \%$ belum berhasil mendapatkan nilai 75 sebagai batas keberhasilan.

Berdasarkan latar belakang di atas dapat dirumuskan permasalahan sebagai berikut: (1) apakah dengan menerapkan strategi bingo dapat meningkatkan hasil belajar sis-wa pada mata pelajaran Fiqih? dan (2) apakah dengan menerapkan strategi bingo dapat meningkatkan aktivitas siswa pada mata pelajaran Fiqih?

Penulisan ini mempunyai tujuan: (1) untuk meningkatkan hasil belajar siswa pada mata pelajaran Fiqih dengan menerapkan strategi bingo, dan (2) untuk meningkatkan aktivitas siswa pada mata pelajaran Fiqih dengan menerapkan strategi bingo.

Manfaat yang diharapkan dari penelitian tersebut adalah sebagai berikut: (1) bagi siswa, dari hasil penelitian ini siswa akan semangat dan aktif dalam melaksanakan proses pembelajaran Fiqih, disamping itu siswa akan mendapatkan pembelajaran yang kondusif, sehingga dimungkinkan dapat meningkatkan hasil belajarnya, (2) bagi guru dari hasil penelitian ini dapat memberikan pengalaman langsung kepada guru-guru yang terlibat dapat 
memperoleh pengalaman baru untuk menerapkan metode yang lebih variatif. Hal ini dapat dijadikan masukan bagi guru, sehingga guru selanjutnya akan selalu berusaha untuk meningkatkan hasil belajar siswa, (3) bagi sekolah/madrasah, dengan mengetahui hasil penelitian ini, hendaknya pihak madrasah memiliki sikap proaktif terhadap setiap usaha guru, mendukung dan memberi kesempatan kepada guru untuk senantiasa meningkatkan kualitas pembelajaran yang akhirnya dapat meningkatkan hasil belajar siswa.

Kajian ini bertujuan untuk memecahkan permasalahan yang muncul diatas yaitu berkenaan dengan rendahnya hasil belajar Fiqih sebagai akibat dari rendahnya aktivitas siswa, pembelajaran yang masih didominasi oleh guru. Dengan cara memberi suatu tindakan kelas karena itu metode yang digunakan dalam penelitian ini adalah metode "Classroom Action Research" atau penelitian tindakan kelas. Dalam pelaksanaannya melibatkan tim kolaboratif.

Dalam pelaksanaanya ada empat tahapan yang dilalui yaitu Perencanaan, Pelaksanaan, Observasi dan Refleksi. Pelaksanaan setiap siklus didasarkan atas masukan dari siklus sebelumnya (Arikunto, dkk., 2007: 17). Prosedur penelitian ini terdiri dari tiga siklus, setiap siklus dalam penelitian tindakan kelas ini meliputi kegiatan.

Perencanaan

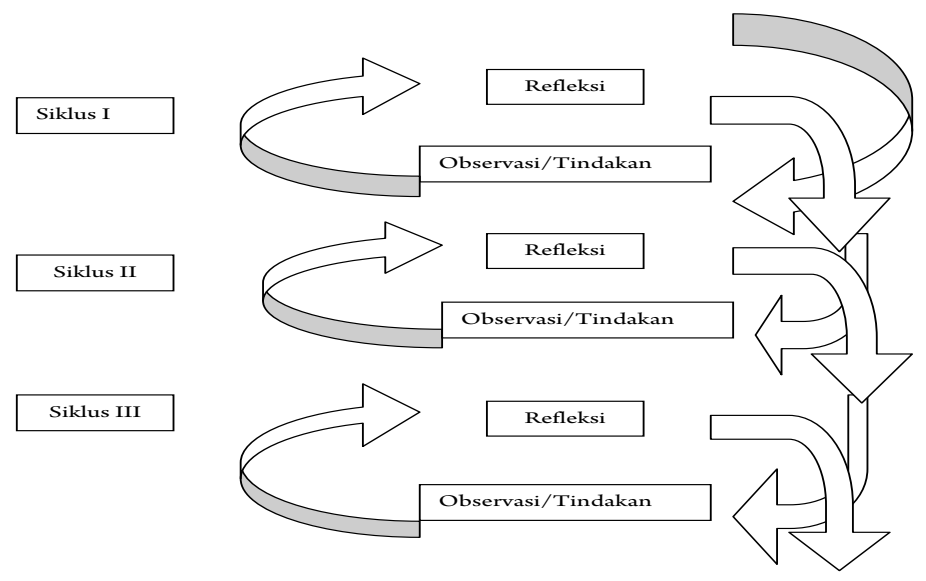

Gambar 1.Tahap Pelaksanaan Penelitian Tindakan Kelas dalam 3 Siklus 
Subjek kajian ini adalah siswa kelas VII MTs Islamic Centre tahun pelajaran 2014/2015. Dengan jumlah 38 siswa dengan rincian 29 siswa putra dan 9 siswa putri. Teknik pengumpulan data dengan menggunakan tes hasil belajar siswa pada mata pelajaran Fiqih pada akhir siklus, lembar observasi aktivitas siswa. Dalam penelitian ini peneliti menggunakan observasi partisipan yakni peneliti terlibat langsung dalam proses kegiatan pembelajaran sebagai guru mata pelajaran Fiqih dan bekerjasama dengan guru mata pelajaran fiqih yang lain. Peneliti menggunakan dokumentasi ini karena seringkali diperoleh makna lebih valid kebenarannya, yakni mencari data mengenai hal-hal yang berupa catatan, transkrip, buku, surat kabar, majalah dan sebagainya (Arikunto, 2002: 206). Metode ini penulis gunakan untuk mendapatkan data rekapitulasi tentang absensi kehadiran, daftar nilai, prestasi siswa dan aktivitas siswa berupa photo selama kegiatan pembelajaran.

Teknik analisis data pada penelitian ini menggunakan statistik deskriptif. Statistik deskriptif menurut Sugiyono (2006: 207) adalah statistik yang digunakan untuk menganalisis data dengan cara mendeskripsikan atau menggambarkan data yang telah terkumpul sebagaimana adanya. Statistik deskriptif untuk mengolah karakteristik data yang berkaitan dengan menjumlah, merata-rata, mencari titik tengah, mencari prosentase serta menyajikan data yang menarik, mudah dibaca, dan diikuti alur berpikirnya misalnya bentuk grafik dan tabel (Arikunto, dkk., 2007: 132). Langkah-langkah yang dilaksanakan dalam analisis data yaitu dengan mengelompokkan data, mentabulasi data, menyajikan data tiap-tiap variabel yang diteliti dan melakukan perhitungan untuk menjawab rumusan masalah. Teknik analisis yang digunakan adalah dengan menghitung prosentase perolehan nilai dan peningkatan nilai pada setiap siklus.

\section{B. Pembahasan}

\section{Strategi Pembelajaran Bingo}

Menurut Ensiklopedia Pendidikan dalam Gulo (2002: 1) strategi adalah "The art of bringing forces to the battle field in favourable position" yakni seni yang membawa pasukan dalam 
medan tempur dalam posisi yang paling menguntungkan. Sedangkan strategi pembelajaran menurut J.R. David dalam Sanjaya (2006: 126) mengatakan sebagai berikut: " a plan, method, or series of activities designed to achieves a particular educational goal" menurut pengertian ini strategi meliputi rencana, metode, dan pe-rangkat kegiatan yang direncanakan untuk mencapai tujuan pengajaran. Dengan demi-kian strategi pembelajaran merupakan rangkaian kegiatan (termasuk rencana, metode, penggunaan berbagai perangkat) yang akan digunakan oleh pengajar untuk mencapai tujuan tertentu sehingga memudahkan peserta didik menerima dan memahami materi pelajaran, yang akhirnya tujuan pembelajaran dapat dicapai secara optimal.

Penelitian ini ditekankan pada peningkatan hasil belajar siswa dengan menerapkan strategi bingo yang dikembangkan oleh Silberman (1996: 133). Strategi bingo merupakan salah satu strategi pembelajaran aktif yang berpusat pada peserta didik, dalam pelaksanaannya guru sebagai pembimbing dan fasilitator bagi peserta didik. Strategi bingo tersebut pertama kali telah dicetuskan oleh Melvin L. Silberman, salah seorang Guru Besar Kajian Psikologi Pendidikan di Temple University. Beliau memiliki reputasi internal dalam proses belajar aktif. Strategi yang diterapkan berbentuk permainan kartu bingo. Dalam hal ini kartu bingo sebagai strategi pembelajaran. Kartu bingo yang dipergunakan sebagai strategi pembelajaran adalah kartu yang dibuat guru sendiri yang di dalamnya memuat pertanyaanpertanyaan tentang materi Fiqih yang akan dipelajari.

Penelitian yang mengkaji tentang strategi bingo telah dilakukan oleh Robingatun pada tahun 2004 dalam skripsi berjudul"Eksperimen Permainan Kartu Bingo dalam Pembelajaran Bahasa Arab pada Siswa Kelas II SDIT Luqman alHakim Yogyakarta”. Hasil dari penelitian ini terdapat perbedaan yang signifikan antara hasil belajar kosa kata bahasa Arab siswa yang menggunakan media kartu bingo dengan siswa yang tidak menggunakan kartu bingo.

\section{Komponen-komponen Strategi Pembelajaran}

Dick dan Carey dalam Uno (2007: 3) menyebutkan bahwa 
terdapat lima komponen strategi pembelajaran yaitu: (1) Kegiatan pembelajaran pendahuluan meliputi menjelaskan indikator yang akan dicapai, melakukan apersepsi, (2) Penyampaian informasi tentang ruang lingkup materi dan materi yang akan disampaikan, (3) Partisipasi peserta didik karena peserta didik merupakan pusat belajar, (4) Tes, (5) Kegiatan lanjutan yaitu peserta didik menerima tindak lanjut dari hasil belajar tersebut.

Adapun materi pelajaran pada umumnya merupakan gabungan antara jenis materi yang berbentuk pengetahuan (fakta dan informasi yang terperinci), keterampilan (langkah-langkah, prosedur, keadaan, dan syarat-syarat tertentu), dan sikap (berisi pendapat, ide, saran, atau tanggapan). Materi pelajaran dapat digolongkan dalam empat kategori, yaitu fakta, prosedur, konsep dan prinsip. Dalam isi pelajaran ini terlihat terlihat masing-masing jenis pelajaran sudah pasti memerlukan strategi penyampaian yang berbeda-beda. Oleh karena itu, dalam menentukan strategi pembelajaran, guru harus terle-bih dahulu memahami jenis materi pelajaran yang akan disampaikan agar diperoleh strategi pembelajaran yang sesuai.

Selanjutnya Gulo (2002: 8) yang mengungkapkan bahwa komponen strategi pembelajaran terdiri atas tujuh komponen yaitu tujuan pengajaran, guru, peserta didik, materi pelajaran, metode pengajaran, media pengajaran serta faktor administrasi dan finansial, yang termasuk dalam komponen ini adalah jadwal pelajaran, kondisi gedung dan ruang belajar.

Kondisi masing-masing komponen masukan dalam strategi pembelajaran tersebut berbeda pada setiap lembaga pendidikan. Oleh karena itu, jika ingin mencapai suatu standar kompetensi yang telah ditetapkan hendaknya perlu memperhatikan komponenkomponen dalam strategi pembelajaran tersebut.

Ada beberapa pertimbangan dalam pemilihan strategi pembelajaran sebagaimana dijelaskan oleh Sanjaya (2006: 130) terdiri dari: (1) pertimbangan yang berhubungan dengan tujuan yang ingin dicapai, (2) pertimbangan yang berhubungan dengan bahan atau materi pembelajaran (materi pembelajaran dapat berupa fakta, konsep, hukum atau teori tertentu), (3) 
pertimbangan dari sudut siswa, yakni dari sisi kematangan siswa, minat, bakat dan kondisi siswa serta gaya belajar siswa.

Dengan demikian sebelum guru menetapkan strategi apa yang akan diterapkan dalam proses belajar mengajar maka harus mempertimbangkan tujuan, materi pembelajaran serta dari siswa itu sendiri sesuai dengan minat dan gaya belajarnya. Berdasarkan beberapa pertimbangan di atas tujuan utamanya adalah agar strategi yang diterapkan efektif dan efisien, maka diperlukan kreativitas guru dalam memilih strategi pembelajaran tersebut. Karena dengan mempertimbangkan berbagai macam hal yang telah disebutkan di atas akan dicapai hasil pembelajaran yang maksimal.

\section{Hasil Belajar Siswa}

Hasil belajar adalah kemampuan-kemampuan yang dimiliki siswa setelah ia menerima pengalaman belajarnya. Bloom dalam Sudjana (1995: 22) mengklasifikasi hasil belajar menjadi tiga ranah yaitu:

1. Ranah kognitif berkaitan dengan hasil belajar intelektual yang terdiri dari enam aspek, yakni pengetahuan atau ingatan, pemahaman, aplikasi, analisis, sintetis dan evaluasi.

2. Ranah afektif berkenaan dengan sikap yang terdiri dari lima aspek, yakni penerimaan, jawaban atau reaksi, penilaian, organisasi dan internalisasi.

3. Ranah psikomotoris berkenaan dengan hasil belajar keterampilan dan kemampuan bertindak.

Ranah afektif tujuan penilaiannya adalah perilaku bukan pengetahuan peserta didik, maka jawabannya tidak harus benar atau salah karena hanya mengukur tentang sikap dan minat peserta didik. Sedangkan dalam ranah psikomotoris pengukurannya disatukan atau dimulai dengan pengukuran ranah kognitif dahulu karena penilaian ditujukan kepada hasil belajar yang berbentuk ketrampilan peserta didik.

\section{Aktivitas Siswa}

Dalam proses pembelajaran peran guru adalah membimbing 
dan memfasilitasi siswa dalam memperoleh pengalaman belajarnya. Thomas M. Risk (Daradjat, dkk., 2004: 137) mengatakan sebagai berikut: "Teaching is the guidance of learning experiences", mengajar adalah proses membimbing, pengalaman belajar.

Pengalaman tersebut dapat dicapai oleh siswa jika siswa aktif terhadap lingkungan belajarnya. Guru dapat membantu siswa belajar, tetapi guru tidak dapat belajar untuk anak itu. Kalau seorang murid ingin belajar memecahkan suatu problem, ia harus berpikir menurut langkah-langkah tertentu; jika ia ingin menguasai suatu keterampilan, ia harus berlatih mengkoordinasikan otototot tertentu, dan kalau ia ingin memiliki sikap-sikap tertentu, ia harus memiliki sejumlah pengalaman emosional. Kegiatan belajar mengajar diperlukan aktivitas, karena pada prinsipnya belajar adalah berbuat, berbuat untuk mengubah tingkah laku, jadi melakukan kegiatan, tidak ada belajar kalau tidak ada aktivitas.

Montessori (Sardiman, 2001: 94) juga menegaskan bahwa anak-anak memiliki tenaga-tenaga untuk berkembang sendiri, membentuk sendiri. Pendidik akan berperan sebagai pembimbing dan mengamati bagaimana perkembangan anak-anak didiknya. Hal ini menunjukkan bahwa yang lebih banyak melakukan aktivitas dalam pembentukan diri adalah anak itu sendiri, sedang pendidik memberikan bimbingan dan merencanakan segala kegiatan yang akan diperbuat oleh anak didik.

Selanjutnya Piaget menjelaskan bahwa seorang anak berpikir sepanjang ia berbuat. Tanpa perbuatan, anak tak berpikir. Agar anak berpikir sendiri, ia harus diberi kesempatan untuk berbuat sendiri. Berpikir pada taraf verbal baru timbul setelah anak berpikir pada taraf perbuatan. Maka dengan demikian aktivitas yang dilakukan siswa dalam proses pembelajaran meliputi aktivitas secara jasmani dan rohani (Nasution, 1995: 89).

Keaktifan jasmani dan rohani meliputi: (1) keaktifan inderawi yaitu pendengaran, penglihatan, peraba dan lain-lain, (2) keaktifan akal meliputi memecahkan masalah, mengambil kesimpulan dan lain-lain, (3) keaktifan ingatan antara lain menerima bahan pengajaran dan menyimpannya dalam otak serta suatu saat siap dan mampu mengutarakan kembali, (4) keaktifan 
emosi meliputi menaruh minat, merasa senang, berani dan lainlain (Sriyono, 1992: 75).

Banyak macam-macam kegiatan yang dapat dilakukan oleh anak-anak dalam kegiatan belajar mengajar di sekolah, peserta didik tidak hanya mencatat dan mendengar-kan tetapi dapat beraktifitas baik aktivitas dari sisi fisik (membaca, bertanya, memperhatikan, mengeluarkan pendapat menggambar, berdiskusi) maupun aktifitas psikis/mental (memecahkan soal, menanggapi, mengingat dan sebagainya).

Aktivitas siswa dalam kegiatan pembelajaran terbagi menjadi berbagai macam yaitu sebagai berikut:

1. Visual activities, seperti membaca, memperhatikan: gambar, demonstrasi, percobaan, pekerjaan orang lain dan sebagainya.

2. Oral activities, seperti menyatakan, merumuskan, bertanya, memberi saran, mengeluarkan pendapat, mengadakan, interview, diskusi, interupsi, dan sebagainya.

3. Listening activities, seperti mendengarkan uraian, percakapan, diskusi, musik, pidato dan sebagainya.

4. Writing activities, seperti menulis cerita, karangan, laporan, tes, angket, menyalin dan sebagainya.

5. Drawing activities, seperti menggambar, membuat grafik, peta, diagram, pola dan sebagainya.

6. Motor activities, seperti melakukan percobaan, membuat konstruksi, model, me-reparasi, bermain, berkebun, memelihara binatang, dan sebagainya.

7. Mental activities, seperti menanggapi, mengingat, memecahkan soal, menganalisis, melihat hubungan, mengambil keputusan dan sebagainya.

8. Emotional activities, seperti menaruh minat, merasa bosan, gembira, berani, tenang, gugup dan sebagainya (Nasution, 1995: 91).

Klasifikasi bentuk kegiatan belajar aktif juga dikemukakan dalam Hamalik (2003: 20) yaitu kegiatan penyelidikan, kegiatan penyajian, kegiatan latihan, apresiasi, kegiatan observasi dan 
mendengarkan, kreatif, bekerja dalam kelompok, percobaan dan kegiatan mengorganisasi dan menilai.

Kegiatan-kegiatan dalam proses pembelajaran tersebut di atas tidak terpisah satu persatu, tetapi aktivitas-aktivitas tersebut saling mendukung diantara satu dengan yang lainnya karena dalam setiap kegiatan motoris terkandung kegiatan mental dan disertai oleh perasaan tertentu. Aktivitas-aktivitas siswa tersebut merupakan prinsip atau asas yang sangat penting dalam interaksi belajar mengajar.

\section{Hasil Tindakan per-Siklus}

Hasil belajar siswa pada siklus I secara lengkap dapat dilihat pada tabel berikut ini.

Tabel 1. Hasil Belajar Siswa pada Siklus I

\begin{tabular}{ccccccc}
\hline Sumber & Skor & \multicolumn{2}{c}{ Hasil Belajar } & \% Berhasil \\
\cline { 1 - 4 } Data & Maksimum & Berhasil & Belum Berhasil & & (Klasikal) \\
\hline Tes Siklus I & 20 & 31 & 7 & 38 & 82 \\
\hline
\end{tabular}

Sedangkan hasil aktivitas siswa pada siklus I dapat diklasifikasikan pada tabel sebagai berikut.

Tabel 2. Klasifikasi Aktivitas Siswa pada Siklus I

\begin{tabular}{clccc}
\hline NO & \multicolumn{1}{c}{ Kriteria } & \multicolumn{2}{c}{ Jumlah } & Prosentase \\
\hline 1 & Sangat kurang & 0 & & 0 \\
\hline 2 & Kurang & 12 & $32 \%$ & \\
\hline 3 & Baik & 15 & $39 \%$ \\
\hline 4 & Sangat baik & 11 & $29 \%$ \\
\hline
\end{tabular}

Hasil belajar dan aktivitas yang dicapai pada siklus kedua ini mengalami pening-katan dapat dilihat pada tabel di bawah ini.

Tabel 3. Hasil Belajar Siswa pada Siklus II

\begin{tabular}{ccccccc}
\hline Sumber & Skor & \multicolumn{2}{c}{ Hasil Belajar } & & \% Berhasil \\
\cline { 1 - 3 } Data & Maksimum & Berhasil & $\begin{array}{c}\text { Belum } \\
\text { Berhasil }\end{array}$ & & & (Klasikal) \\
\hline Tes Siklus II & 20 & 36 & 2 & 38 & 95 \\
\hline
\end{tabular}

Tabel 4. Klasifikasi Aktivitas Siswa pada Siklus II 


\begin{tabular}{|c|c|c|c|}
\hline No & Kriteria & Jumlah & Prosentase \\
\hline 1 & Sangat kurang & 0 & 0 \\
\hline 2 & Kurang & 2 & $5 \%$ \\
\hline 3 & Baik & 17 & $45 \%$ \\
\hline 4 & Sangat baik & 19 & $50 \%$ \\
\hline
\end{tabular}

Selanjutnya pada siklus III hasil belajar siswa mencapai keberhasilan $100 \%$ dapat dilihat pada tabel di bawah ini.

Tabel 5. Hasil Belajar Siswa pada Siklus III

\begin{tabular}{ccccccc}
\hline Sumber & Skor & \multicolumn{2}{c}{ Hasil Belajar } & \multirow{2}{*}{ Jumlah } & & \% Berhasil \\
\cline { 1 - 3 } Data & Maksimum & Berhasil & $\begin{array}{c}\text { Belum } \\
\text { Berhasil }\end{array}$ & & (Klasikal) \\
\hline Tes Siklus III & 20 & 38 & 0 & 38 & 100 \\
\hline
\end{tabular}

Aktivitas dalam kegiatan pembelajaran dapat dilihat pada tabel berikut ini.

Tabel 6. Klasifikasi Aktivitas Siswa pada Siklus III

\begin{tabular}{clccc}
\hline No & \multicolumn{1}{c}{ Kriteria } & \multicolumn{2}{c}{ Jumlah } & Prosentase \\
\hline 1 & Sangat kurang & & 0 & 0 \\
\hline 2 & Kurang & 0 & 0 & \\
\hline 3 & Baik & 14 & $37 \%$ & \\
\hline 4 & Sangat baik & 24 & $63 \%$ \\
\hline
\end{tabular}

\section{Analisis Hasil Tindakan per-Siklus}

Proses pembelajaran yang pasif atau peserta didik hanya mendengarkan dari guru, memiliki kecenderungan untuk cepat melupakan apa yang telah diberikan. Maka diperlukan perangkat tertentu untuk dapat mengikat informasi yang telah diberikan oleh guru salah satunya dengan pembelajaran aktif. Belajar aktif merupakan salah satu cara untuk mengikat informasi tersebut dan menyimpannya dalam otak. Karena peserta didik jika hanya mendengarkan memiliki beberapa kelemahan, padahal hasil belajar harus di-simpan dalam waktu yang lama. Kondisi ini selaras dengan apa yang diungkapkan oleh Konfusius, seorang filosuf kenamaan berpendapat bahwa apa yang saya dengar, saya lupa, apa yang saya lihat, saya ingat, apa yang saya lakukan saya paham.

Dengan strategi bingo siswa dalam kegiatan pembelajaran 
merasa senang, tidak jenuh dalam belajar. Semangat belajarnya meningkat karena setiap pertemuan siswa se-makin aktif membaca buku pelajaran, belajar bersama, menjawab pertanyaan, bertanya kepada guru jika belum jelas, mengerjakan tugas dan sebagainya. Keaktifan siswa da-lam pembelajaran berakibat pada meningkatnya hasil belajar siswa.

Terbukti bahwa sebelum dilakukan tindakan prosentase keberhasilan siswa sebesar $21 \%$ (8 siswa), Selanjutnya hasil belajar siswa pada siklus I sampai siklus III me-ngalami peningkatan jumlah siswa yang memperoleh nilai $\geq 60$ dengan rincian pada siklus I jumlah siswa yang berhasil memperoleh nilai $\geq 60$ ada 31 dengan rata-rata kelas 63,81 prosentase keberhasilan mencapai 82 $\%$, kemudian pada siklus II berjumlah 36 siswa dengan rata-rata kelas 68,42 prosentase keberhasilan siswa sebesar $95 \%$, selanjutnya pada siklus III berjumlah 38 siswa dengan rata-rata kelas 74 atau keberhasilan siswa mencapai $100 \%$.

Untuk lebih jelas melihat peningkatan hasil belajar siswa dapat dilihat pada tabel 7 di bawah ini.

Tabel 7. Peningkatan Hasil Belajar Siswa pada Siklus I, II, dan III

\begin{tabular}{lccc} 
Keterangan & Siklus I & Siklus II & Siklus III \\
\hline Siswa yang Berhasil & 31 & 36 & 38 \\
\hline Siswa yang Belum Berhasil & 7 & 2 & 0 \\
\hline Rata-rata & 26 & 29 & 30.15 \\
\hline $\begin{array}{l}\text { Prosentase Keberhasilan } \\
\text { Peningkatan hasil belajar siswa }\end{array}$ & 82 & 95 & 100 \\
dapat digambarkan sebagai berikut: &
\end{tabular}


Zaenudin

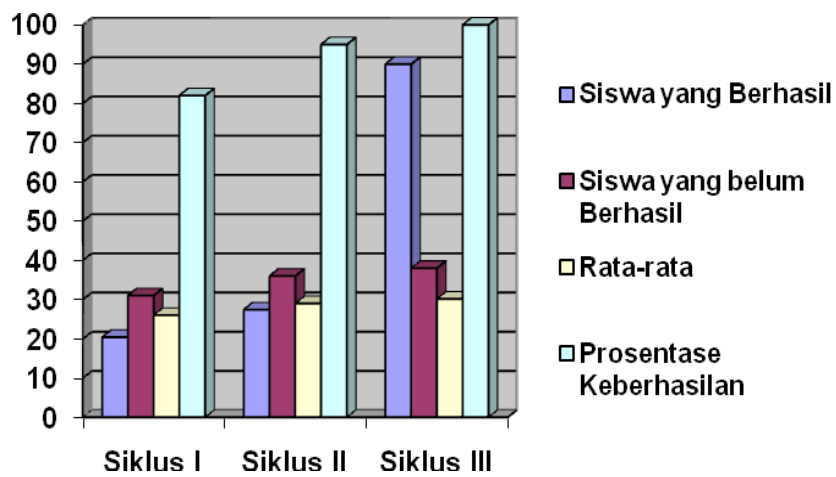

Gambar 2. Diagram Peningkatan Hasil Belajar Siswa pada Siklus I, II, dan III

Aktivitas siswa kelas VII dari siklus I sampai dengan siklus III adalah tinggi, mengalami peningkatan dari rata-rata aktivitas siswa dari 26 pada siklus I dan aktivitas siswa $68 \%$, kemudian rata-rata pada siklus II mencapai 29 dengan prosentase aktivitas $95 \%$. Hal ini berarti sudah melampaui indikator penelitian yang ditetapkan. Sedangkan pada siklus yang III rata-rata kelas mencapai 30,15 dengan prosentase aktivitas siswa sebesar $100 \%$.

Hasil peningkatan aktivitas siswa pada siklus I, II, dan III dapat dilihat pada tabel 8. berikut ini.

Tabel 8. Peningkatan Aktivitas Siswa pada Siklus I, II, dan III

\begin{tabular}{lccc}
\hline Keterangan & Siklus I & Siklus II & Siklus III \\
\hline Sangat Kurang & 0 & 0 & 0 \\
\hline Kurang & 12 & 2 & 0 \\
\hline Baik & 15 & 17 & 14 \\
\hline Sangat Baik & 11 & 19 & 24 \\
\hline Rata-rata & 26 & 29 & 30.15 \\
\hline Prosentase Aktivitas & 68 & 95 & 100 \\
\hline
\end{tabular}

Peningkatan aktivitas dari siklus I, II, dan III tersebut dapat digambarkan sebagai berikut: 


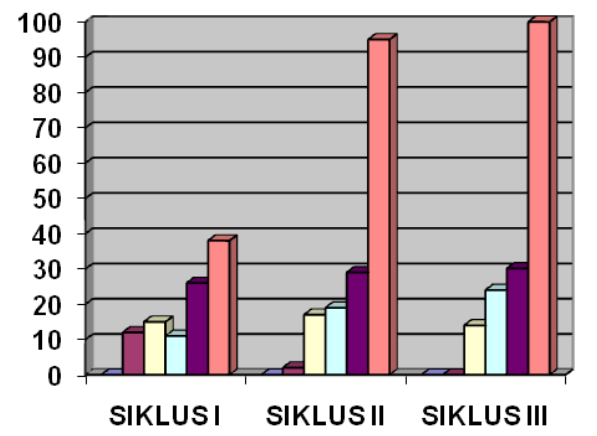

口Sangat Kurang

口Kurang

口Baik

口Sangat Baik

QRata-rata

口Prosentase

Aktivitas

Gambar 3. Diagram Peningkatan Aktivitas Siswa dari Siklus I, II, dan III

Aktivitas siswa yang menyenangkan, bersemangat dalam belajar, antusias dalam proses pembelajaran, menjawab pertanyaan dari berbagai referensi, memahami materi pelajaran siswa dapat menyimpannya dalam waktu lama, sehingga hasil belajar dapat ditingkatkan.

Sedangkan prosentase hasil angket tanggapan siswa terhadap strategi bingo dapat dikategorikan tinggi yaitu sekitar $80 \%$ sampai $97 \%$ siswa setuju sampai sangat setuju dan sering sampai selalu untuk menerapkan strategi bingo dalam mata pelajaran Fiqih.

Hasil analisis dalam tindakan kelas ini menunjukkan bahwa dengan menerapkan strategi bingo dapat meningkatkan aktivitas siswa dan hasil belajar siswa pada mata pelajaran Fiqih siswa kelas VII MTs Islamic Centre Kudus. Siswa selama dalam proses pembelajaran merasa menyenangkan, semangat belajarnya meningkat, dapat lebih memahami materi pelajaran, hal ini didukung dengan hasil angket tanggapan siswa pada mata pelajaran Fiqih.

\section{Simpulan}

Dari penelitian yang penulis lakukan dapat disimpulkan sebagai berikut: (1) stra-tegi bingo dapat meningkatkan hasil belajar siswa pada mata pelajaran Fiqih, (2) strategi bingo dapat meningkatkan aktivitas siswa pada mata pelajaran Fiqih. Guru mata pelajaran Fiqih atau mungkin mata pelajaran yang lain 


\section{Zaenudin}

hendaknya menerapkan strategi bingo, karena dengan menerapkan strategi bingo dapat meningkatkan hasil belajar siswa. Strategi bingo diharapkan dapat menjadi salah satu alternatif pembelajaran Fiqih. Perlu adanya dukungan dan dorongan dari pihak sekolah terhadap guru yang mempunyai semangat inovasi pembelajaran dalam upaya meningkatkan mutu hasil pendidikan. 


\section{Daftar Pustaka}

Arikunto, Suharsimi., Suhardjono, \& Supardi. 2006. Penelitian Tindakan Kelas. Jakarta: Bumi Aksara.

Arikunto, Suharsimi. 2002. Prosedur Penelitian Suatu Pendekatan Praktek. Yogyakarta: Rineka Cipta.

Badan Standar Nasional Pendidikan. 2007. Kurikulum Tingkat Satuan Pendidikan Khusus Madrasah Tsanawiyah (MTs). Jakarta: PT Binatama Raya.

Daradjat, Zakiah. dkk. 2004. Metodik Khusus Pengajaran Agama Islam. Jakarta: Bumi Aksara.

Departemen Agama RI. 2006. Standar Isi Madrasah Tsanawiyah. Jakarta: Direktorat Jenderal Kelembagaan Agama Islam.

Gulo W. 2002. Strategi Belajar Mengajar. Jakarta: PT Gramedia.

Hamalik, Oemar. 2003. Pendekatan Baru Strategi Belajar Mengajar Berdasarkan CBSA. Bandung: Sinar Baru Algesindo.

Nasution. 1995. Didaktik Asas-asas Mengajar. Jakarta: Bumi Aksara.

Nana, Sudjana, 1995. Penilaian Hasil Proses Belajar Mengajar. Bandung: Remaja Rosdakarya.

Robingatun. Skripsi. 2004. Eksperimen Kartu Bingo dalam Pembelajaran Bahasa Arab pada Siswa Kelas II SDIT Luqman al-Hakim Yogyakarta. Yogyakarta: IAIN Sunan Kalijaga.

Sanjaya, Wina. 2006. Strategi Pembelajaran Berorientasi Standar Proses Pendidikan. Jakarta: Kencana.

Sardiman. 2001. Interaksi dan Motivasi Belajar Mengajar. Jakarta: PT RajaGrafindo Persada.

Silberman, Melvin L. 1996. Active Learning: 101 Strategi Pembelajaran Aktif. Penerjemah: Raisul Muttaqien. Bandung: Nusamedia. 
Zaenudin

Siswono, Sudayat. Tesis. 2006. Optimalisasi Aktivitas dan Hasil Belajar Matematika dengan Menggunakan Program Aplikasi Powerpoint pada Siswa Kelas VII SMP Islam Roudlotus Saidiyah, Semarang: Universitas Negeri Semarang.

Sriyono. 1992. Teknik Belajar Mengajar dalam CBSA. Jakarta: Rineka Cipta.

Sugiyono. 2006. Metode Penelitian Kuantitatif Kualitatif dan RઐD. Cet. II. Bandung: Alfabeta.

Uno. Hamzah B. 2007. Model Pembelajaran Menciptakan Proses Belajar yang Kreatif dan Efektif. Jakarta: Bumi Aksara. 